(C) 1983 ISIJ

\title{
橋梁における高力ボルトの遅れ破壊
}

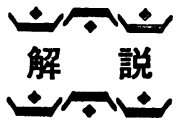

松山 晋 作*

\section{Delayed Fracture of High Strength Bolts Used for Bridges \\ Shinsaku MATsUyamA}

\section{1.はじめに}

鋼構造物の現場接合の主力がリベットから高力ボルト に移つたのには, 構造物の大型化に必要な部材比強度の 向上，施工管理の容易さ，高強度材料の開発といつた技 術的背景と, 熟練を要するリベット工の不足, 騒音の防 止といつた社会的な背景があつた.

我が国の高力ボルト適用の経過は, 表 1 に示すように 1954 年の非調質 $6 \mathrm{~T}$ 級 $\left(\sigma_{\mathrm{B}} \geq 60 \mathrm{kgf} / \mathrm{mm}^{2}\right)$ の鉄道橋へ の試用から始まつた1). その後 1956 年より調質 $8 \mathrm{~T}$ 級 $\left(\sigma_{\mathrm{B}} \geq 80 \mathrm{kgf} / \mathrm{mm}^{2}\right), 1962$ 年には $11 \mathrm{~T}$ 級 $\left(\sigma_{\mathrm{B}} \geq 110 \mathrm{kgf}\right.$ $\left./ \mathrm{mm}^{2}\right), 1964$ 年には $13 \mathrm{~T}$ 級 $\left(\sigma_{\mathrm{B}} \geq 130 \mathrm{kgf} / \mathrm{mm}^{2}\right)$ とし だいに高強度化が進んだ. ところが，13 T 級ボルトを 適用したすべての橋梁で遅れ破壊を生じたため，1967 年の JIS B 1186 改訂時には $13 \mathrm{~T}$ 級は規格からはずさ れた.このとき各強度等級の引張強さ範囲に上限が定め られ F $11 \mathrm{~T}$ に対しては $110 \sim 130 \mathrm{kgf} / \mathrm{mm}^{2}$ となつた。 この間, 経済の高度成長を反映して高力ボルトの需要 は急速に払大し, 最強等級となつた F $11 \mathrm{~T}$ の使用実績 は著しく増大した。

$11 \mathrm{~T}$ 級以下のボルトについては, 一部に熱処理不良 による遅れ破壊事例2)31はあつたものの，正常な $11 \mathrm{~T} な$ らば遅れ破壊は生じないと考えられていた。 ところが,
1977 年以降規格範囲を完全に満足する F $11 \mathrm{~T}$ ボルト の遅れ破壊事例4)が報告されるに及んで，11 T 級でも遅 れ破壊の危険性があることがわかり，1979 年の JIS 改 訂時には F 11 T を使用しないように勧告がなされるに 至つた。

本報は過去約 15 年にわたり鉄道橋で生じた高力ボル トの遅れ破壊の事例解析を総括したものである.

\section{2. 高力ボルトの締付条件}

ボルトの締付はトルク法によるもので，その基本的な 施工条件は次のとおりである.

ボルトの設計軸力 $N$ は降伏点の $90 \%$ に相当する荷重 とし，締付時にねじ面の摩擦によつて導入されるねじり 応力成分を考虑した係数を $1 / 1.22$ とすれば次のよらに 表される.

$$
N=\frac{0.9}{1.22} \cdot \sigma_{\mathrm{Y}} \cdot A_{\mathrm{e}}=0.74 \sigma_{\mathrm{Y}} \cdot A_{\mathrm{e}}
$$

ただし， $\sigma_{\mathrm{Y}}$ はボルト材の降伏点で規格に示された耐 力範囲の下限值を用いる. $A_{\mathrm{e}}$ はねじ部有効断面積であ る. 締付トルクは次式により求める.

$$
T=k d N_{0}
$$

ただし， $k$ はトルク係数でボルト種別（寸法, 熱処理 ロットなど）ごとに検定する。 $d$ はボルト公称直径， $N_{0}$

表 1 日本における高力ボルト採用の経過

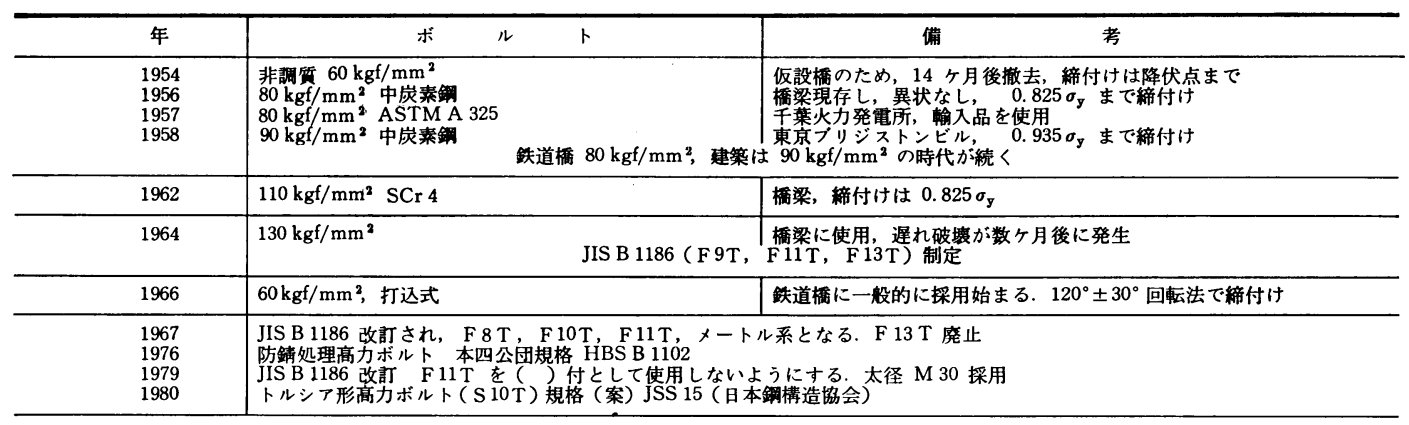

昭和 58 年 1 月 7 日受付 (Received Jan. 7，1983)（依頼解説)

* 鉄道技術研究所 (Railway Technical Research Institute, JNR, 2-8-38 Hikari-cho Kokubunji 185) 
表 2 鉄道橋における高力ボルトの遅れ破壊例

\begin{tabular}{|c|c|c|c|c|c|c|c|c|c|c|}
\hline \multirow{2}{*}{ 橋梁 } & \multirow{2}{*}{$\begin{array}{l}\text { 术儿卡 } \\
\text { 強度等級 }\end{array}$} & \multirow{2}{*}{ 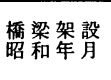 } & \multirow{2}{*}{ 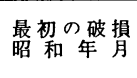 } & \multirow{2}{*}{$\begin{array}{l}\text { 最初の破椇 } \\
\text { での時(間(肘) }\end{array}$} & \multirow{2}{*}{ ボルト破損䇢所 } & \multicolumn{4}{|c|}{ ボルト破 損 数 } & \multirow{2}{*}{ 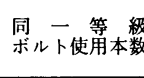 } \\
\hline & & & & & & 上フランジ & 下フランジ & ウェブ & 計 & \\
\hline 1 & $11 \mathrm{~T}$ & $38-3$ & $38-5$ & 2 & $\begin{array}{l}\text { I型主 析 } \\
\text { 上下フジシ }\end{array}$ & 1 & 1 & - & 2 & 720 \\
\hline 2 & $11 \mathrm{~T}$ & $39-9$ & $43-1$ & 40 & 箱 型ラ主ン晳 & - & 3 & - & 3 & 5500 \\
\hline 3 & $11 \mathrm{~T}$ & $40-10$ & $42-2$ & 16 & $\begin{array}{l}\text { 箱下型主梊 } \\
\text { 上丨ン济 }\end{array}$ & 7 & 1 & - & 10 & 6515 \\
\hline 4 & $13 \mathrm{~T}$ & $40-12$ & $42-8$ & 20 & $\begin{array}{l}\text { I 型 主析 } \\
\text { 上下フランジ }\end{array}$ & 7 & 56 & - & 63 & 2384 \\
\hline 5 & $11 \mathrm{~T}$ & $42-12$ & $45-10$ & 34 & 箱型 主 晳 & - & 4 & - & 7 & 2686 \\
\hline 6 & $6 \mathrm{~T}$ & $44-3$ & $44-8$ & 5 & 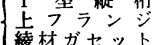 & - & - & - & 27 & 3095 \\
\hline 7 & $11 \mathrm{~T}$ & $46-7$ & $55-7$ & 108 & 箱下フ型主梅 & 13 & 4 & 2 & 20 & 7400 \\
\hline 8 & $11 \mathrm{~T}$ & $48-7$ & $52-6$ & 47 & 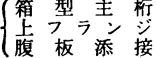 & - & 1 & 16 & 17 & 2486 \\
\hline 9 & $11 \mathrm{~T}$ & 49 & 53-8 & $\sim 48$ & $\begin{array}{l}\text { 箱下型 隹森 } \\
\text { 上下ンジ }\end{array}$ & 1 & 20 & - & 29 & 4536 \\
\hline 10 & $11 \mathrm{~T}$ & $49-$ & $54-5$ & $\sim 60$ & 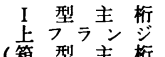 & 3 & - & - & 4 & 454 \\
\hline 11 & $11 \mathrm{~T}$ & $50-3$ & $55-7$ & 64 & 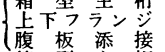 & - & 2 & 1 & 3 & 4000 \\
\hline 12 & $11 \mathrm{~T}$ & $50-5$ & $55-7$ & 62 & $\begin{array}{l}\text { 箱型 主 析 } \\
\text { 晳 }\end{array}$ & 3 & 1 & - & 6 & 15000 \\
\hline 13 & $11 \mathrm{~T}$ & $50-$ & $55-7$ & $\sim 60$ & $\begin{array}{cccc}\text { I } & \text { 型 } & \text { 綾 } & \text { 材 } \\
\text { ガ } & \text { 七 } & \text { \% } & \text { 卜 }\end{array}$ & - & 1 & - & 1 & - \\
\hline
\end{tabular}

は目標導入軸力で，リラクゼーションやクリープによる 軸力緩和を補らために $N_{0}=1.1 N$ とし，10\%の増し締 めを行ら。ただし，後述する F 13 T 級については遅れ 破壊の危検性を緩和するために $N_{0}=N$ とした。

設計軸力 $N$ は F 11 T では M 22 で $21.7 \mathrm{t}$, W 7/8 で $21.0 \mathrm{t}, \mathrm{F} 13 \mathrm{~T}$ では W 7/8 で $24.3 \mathrm{t}$, 目標導入軸力 はその $10 \%$ 増であるから，F 11 T では M 22 で 23.9 $\mathrm{t}, \mathrm{W} 7 / 8$ で $23.1 \mathrm{t}$ である.

\section{3. 高力ボルトの使用状況と破損経過}

鉄道橋においてこれまでに遅れ破壊を生じた高力ボル トの使用状況及び破損経過を橋梁の架設年代順に表 2 に 示す. No. 2, 3, 6 および 13 については後述するよう に熱処理上問題のあつたもので, 該当規格範囲を満足し ていない製品であつた. とくに No. 6 は F 6 T であり ながら実際の強度水準は $12 \mathrm{~T}$ 級に調質されていたもの である.

No. 4 の F 13 T は適用時にすでに道路橋において遅 れ破壊の発生がみられていたが, 当時遅れ破壊の実態が 明らかになつていなかつたため試験的に使用したもので ある.ただし，締付条件は前述したように軸力緩和を補 ら $10 \%$ の追い締めを行わなかつたので，導入軸力は F $11 \mathrm{~T}$ 並である. またこの場合のみは軸部にも防錆の ため光明丹を塗布した.

以上に述べたボルト以外は，すべて機械的性質が規格 範囲を満足する F $11 \mathrm{~T}$ ボルトである.これら F $11 \mathrm{~T}$ ボルトにおける破損の大部分は箱桁に用いられていたも のに生じた. 箱桁は完全な気密構造にはなつておらず,
板の隅部やマンホール蓋には雨水の浸入する隙間がある ため,ここに挙げた橋梁ではいずれも桁内部に水が溜つ ていた。 そのため桁内部は湿度が飽和状態で内壁には水 滴が付着しており，日照時には温度が上昇して腐食反応 を促進したと考えられる。とくに夏期にはボルトの温度 は $50^{\circ} \mathrm{C}$ 程度まで上昇する。このような高温高湿条件は 遅れ破壊促進試験法としても用いられており，通常の大 気曝露条件よりも遅れ破壞寿命の短縮および破壊発生確 率の増大を伴うことが認められている5).

ボルトは前述の No. 4 の場合を除いて軸部は無塗装 で，締結後に外に出た面だけが塗装された。遅れ破壊を 生じた継手で破損していない他のボルトを参考のために 抜き取ると，軸部は水滴が付着していたり湿つた状態に あることが多かつた。

破損の最初の発見年月は必ずしも最初の破損発生年月 とは一致しない. とくに下フランジのよらに見えにくい 場所での破損は発見が遅れる.しかし一般には最初の破 損が発見された時期に破損が集中して生ずることが多い ことから，これらの発見年月は破損発生年月と大きな差 はないと思われる．ボルト締結後破損発見までの時間は No. 1 および 6 のように数ヶ月のものから, No. 7 のよ うに 9 年にわたるものまである. しかし破損本数とこれ らの寿命との間には明瞭な相関性はない。たとえば, No. 1 は締結後 2 ヶ月で 1 本の破損が発見されたが，そ の後 14 年間に破損本数は 1 本増えたのみであつた. 他 方, No. 7 では締結後 9 年経過して破損が 発見された が，その後破損が継続して生じた.

各橋梁に挴けるボルトの破損はある箇所に集中する傾 
向がある.たとえば, 箱桁の場合, No. 3 および 7 では 上フランジで, No. 4, 5 抽よ゙゙ 9 では下フランジで，ま た No. 8 ではウェブでの破損が多かつた．一般に同一 橋梁用に発注された同一強度等級のボルトは連続炉で熱 処理されているために同一品質とみなせるが, No. 3 の みはバッチ型焼もどし炬で処理されたためボルト長さ別 に材質が若干異なる可能性がある. また No. 8 以外に は箱桁のウェブでの破損がみられないのは， ウェブに F 9 T が使用されているためである. I 型主桁の場合も No. 4 では下フランジの破損が圧倒的に多いのに対し, No. 10 では上フランジにのみ破損を生じている. この ようにある箇所に破損が集中する原因は明らかではない が，ボルトの材質によるよりもむしろボルト長さが異な るためにグリップ長さやナット端から不完全ねじ部まで の遊びねじ長さの差により軸力に差異を生じたり，下フ ランジは雨水が溜まりやすいとか, 上フランジは日照に より温度が上昇しやすいといつた環境条件の差異による ものと考光られる。

\section{4. 遅れ破壊したボルトの材質}

破損ボルトの化学成分を表 3 に示す．摩擦接合用高力 ボルトは開発の初期には中炭素系のクロム鋼，クロムモ リブデン鋼が多く用いられてきた．ところが F 13 T の 適用に当たつて，中炭素鋼では焼もどし特性曲線の勾配 の大きい温度領域での焼もどしが避けられず, 焼もどし 温度のわずかの変化が強度に大きく影響するため, 高力 ボルト用鋼としては低炭素系鋼種の開発が進められた。

No. 4 扎よび 5 はその代表例である. さらに近年では Cr p Mo などの合金元素の高騰化とともに，低廉で焼 入性のよい Mn-B 系の材料が多用されるようになつた。 これらは現行 JIS には該当規格がなく SAE 規格系によ つている.

表 4 はボルト製造成績表に記載された機械的性質を示 したもので，すでに記録の失われたものについては破損 品の軸部最高硬さのみを示した，この硬さは図 1 に示す ボルト軸部横断面の硬さ分布で最大值を示す表面下約 3

表 3 遅れ破壊を生じたボルトの化学成分

\begin{tabular}{|c|c|c|c|c|c|c|c|c|c|c|c|c|c|c|}
\hline 橋梁 No & C & $\mathrm{Si}$ & $\mathrm{Mn}$ & $P$ & $\mathrm{~S}$ & $\mathrm{Cu}$ & $\mathrm{Cr}$ & Mo & B & $\mathrm{Al}$ & $\mathrm{N}$ & $\mathrm{Ti}$ & 相 当 & 規 格 品 \\
\hline 1 & 0.4 & 0.25 & 0.69 & - & - & - & 1. 13 & - & 0.0008 & - & - & - & \multirow{5}{*}{\multicolumn{2}{|c|}{$\begin{array}{l}\text { SCr } 440 \\
\text { SCr } 440 \\
\text { SCM435 }\end{array}$}} \\
\hline 2 & 0.38 & 0.28 & 0.73 & 0.013 & 0.019 & 0.14 & 1. 02 & - & - & - & - & - & & \\
\hline 3 & 0.35 & 0.29 & 0.69 & 0.020 & 0.013 & 0.18 & 0.97 & 0.16 & - & - & - & - & & \\
\hline 4 & 0.20 & 0.78 & 1.14 & 0.017 & 0.009 & 0.19 & 1. 36 & - & - & - & - & - & & \\
\hline 5 & 0.19 & 0.47 & 1. 36 & 0.009 & 0.007 & - & 0.50 & - & 0.0023 & - & - & - & & \\
\hline 6 & 0.42 & 0.29 & 1.50 & 0.015 & 0.020 & 0.020 & 0.20 & - & - & - & - & - & \multirow{8}{*}{ SAE } & 1541 \\
\hline 7 & 0.32 & 0.28 & 0.74 & 0.010 & 0.016 & - & 0.11 & - & 0.0047 & 0.015 & 0.002 & 0.038 & & $10 \mathrm{~B} 30$ \\
\hline 8 & 0.33 & 0.27 & 0.78 & 0.017 & 0.014 & 0.01 & 0.17 & - & 0.0037 & - & - & - & & $10 \mathrm{~B} 30$ \\
\hline $\begin{array}{l}8 \\
9\end{array}$ & 0.24 & 0.28 & 1.10 & 0.018 & 0.026 & - & - & - & 0.002 & 0.024 & 0.0052 & - & & 15 B 24 \\
\hline 10 & 0.29 & 0.16 & 1.57 & 0.007 & 0.012 & - & 0.16 & - & 0.0020 & 0.024 & 0.004 & - & & $15 \mathrm{~B} 27$ \\
\hline 11 & 0.30 & 0.23 & 1.50 & 0.010 & 0.012 & - & 0.14 & - & 0.002 & 0.046 & - & - & & $15 \mathrm{~B} 36$ \\
\hline 12 & 0.32 & 0.21 & 1. 45 & 0.010 & 0.016 & - & 0.16 & - & 0.0021 & 0.023 & 0.004 & $0 . \overline{029}$ & & $15 \mathrm{~B} 36$ \\
\hline 13 & 0.25 & 0.09 & 0.91 & 0.025 & 0.011 & - & 0.63 & - & 0.004 & 0.058 & - & - & & $10 \mathrm{~B} 26$ \\
\hline
\end{tabular}

表 4 遅れ破壞を生じたボルトの素材および完成品の機械的性質

\begin{tabular}{|c|c|c|c|c|c|c|c|c|c|c|}
\hline \multirow{3}{*}{ 橋梁 No } & \multicolumn{2}{|r|}{ 素 } & \multicolumn{3}{|c|}{ 材 (JIS 4 号) } & \multicolumn{4}{|c|}{ 完 成 } & \multirow{3}{*}{ 熱 処 理 } \\
\hline & \multirow{2}{*}{ 耐 $\underset{\mathrm{kgf} / \mathrm{mm}^{2}}{\text { 力 }}$} & \multirow{2}{*}{$\begin{array}{l}\text { 引張強さ } \\
\mathrm{kgf} / \mathrm{mm}^{2}\end{array}$} & \multirow{2}{*}{ 伸 $\%$} & \multirow{2}{*}{ 絞 ${ }_{\%} \eta$} & \multirow{2}{*}{$\begin{array}{c}\text { シャルピー值 } \\
\mathrm{kgf} \cdot \mathrm{m} / \mathrm{cm}^{2}\end{array}$} & \multirow{2}{*}{ 呼び径 } & \multirow{2}{*}{ 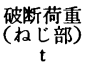 } & \multicolumn{2}{|c|}{ 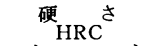 } & \\
\hline & & & & & & & & 1) & 2) & \\
\hline 1 & - & - & - & - & - & W7/8 & - & - & 40 & - \\
\hline 2 & 112 & 118 & 16. 7 & 49.0 & - & W7/8 & 36.3 & 37.1 & 46 & $\begin{array}{l}850^{\circ} \mathrm{COQ} \\
500^{\circ} \mathrm{COC}\end{array}$ \\
\hline 3 & 117 & 123 & 17 & 53 & 13. 8 & $\mathrm{~W} 7 / 8$ & 36.4 & 37 & 38 & $\begin{array}{l}860^{\circ} \mathrm{COQ} \\
550^{\circ} \mathrm{CWC}\end{array}$ \\
\hline 4 & 122 & 145 & 16.1 & 57.3 & 7.4 & $\mathrm{~W} 7 / 8$ & 44.5 & 41.6 & 45 & $\begin{array}{l}870 \sim 900^{\circ} \mathrm{COQ} \\
275 \sim 325^{\circ} \mathrm{COC}\end{array}$ \\
\hline 5 & - & - & - & - & - & $\mathrm{W} 7 / 8$ & - & - & 39 & - \\
\hline 6 & 74 & 90 & 22 & 59 & 15 & W7/8 & 23.2 & - & 41.5 & $\begin{array}{l}850^{\circ} \mathrm{COQ} \\
580^{\circ} \mathrm{CWC}\end{array}$ \\
\hline 7 & - & - & - & - & - & W7/8 & - & - & 40 & \\
\hline 8 & 112 & 120 & 18. 6 & 62 & - & $\mathrm{W} 7 / 8$ & 35.1 & 36.0 & 37.5 & $\begin{array}{l}850 \sim 880^{\circ} \mathrm{CWQ} \\
420 \sim 425^{\circ} \mathrm{CWC},\end{array}$ \\
\hline 9 & 113 & 120 & 18. 0 & 65.6 & - & M22 & 36.2 & 36 & 40.5 & \\
\hline 10 & 113 & 120 & 18. 0 & 63.0 & - & M22 & 36.1 & 37.0 & 42 & $\begin{array}{l}880^{\circ} \mathrm{CWQ} \\
420^{\circ} \mathrm{CWC}\end{array}$ \\
\hline 11 & - & - & - & - & - & M22 & - & - & 42 & \\
\hline 12 & - & - & - & - & - & M22 & - & - & 38 & \\
\hline 13 & - & - & - & - & - & M22 & - & - & 44 & \\
\hline
\end{tabular}

注：1）ボルト頭部側面２）ボルト軸部横断面における最高硬さ 


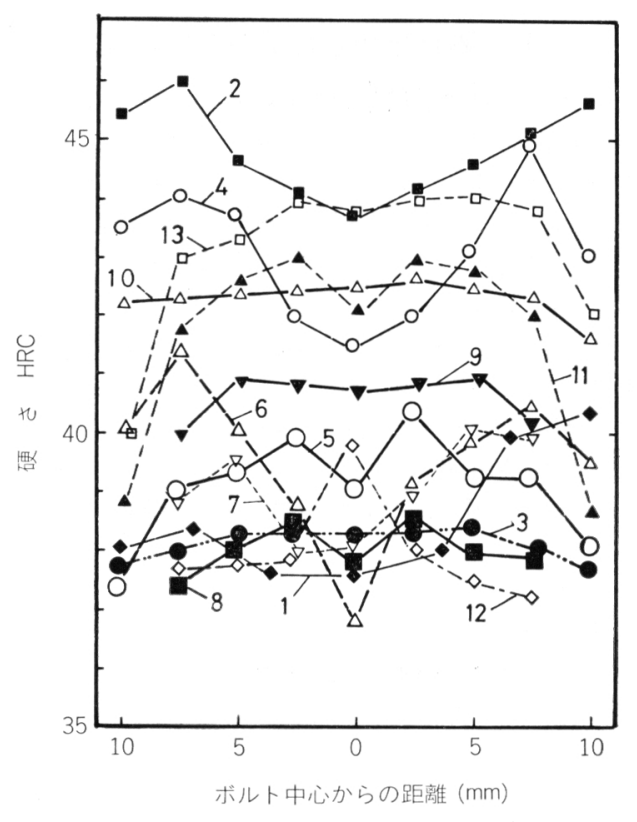

困 1 破損ボルト軸部横断面の硬さ分布

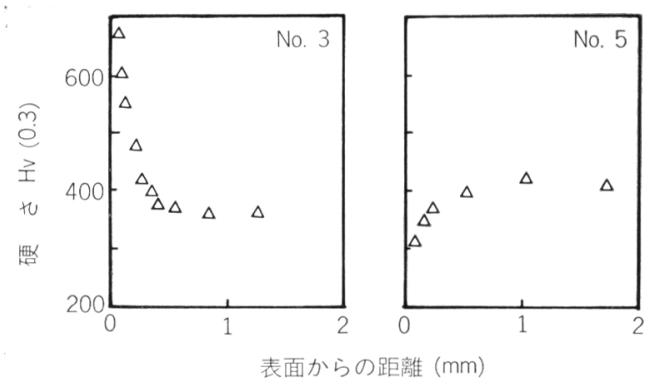

四 2 破損ボルト軸部表面下の硬さ分布代表例

$\mathrm{mm}$ での值である. 表面直下の硬さ分布は, 四 2 亿示す よらに No. 3 のみは硬化層の存在を示し, 他は代表例 No. 5 の場合のよらに軟化層の存在を示した.

ピクリン酸飽和水溶液に表面活性剂としてドデシベル ベンゼンスルホン酸ナトリウム特よびェーテルを加えた 腐食液は，マルテンサイトラスに沿つた炭化物などは現 出しにくいが, 旧オーステナイト粒界とミクロ偏析帯を 現出する。ここでミク口偏析帯とは，Mn 等の樹枝状晶 間偏析に起因し圧延方向に帯状に現出されるもので，顕 微鏡組織的には均一な焼もどしマルテンサイト相であ る。

旧オーステナイト粒界が現れるのはPの粒界偏析によ るものであり, 粒界の現出されやすさは遅れ破壊感受性 の一つの目安となる ${ }^{6)}$. 写真 1 は破損ボルト鋼の粒界現 出度の代表的な 3 例である. 粒界が全面に現出されたの

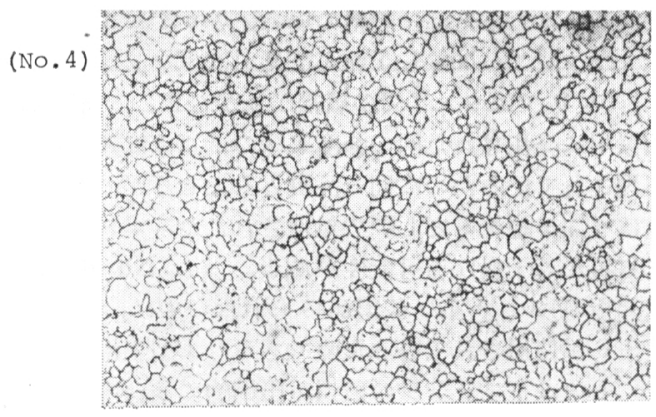

a) 全面に現出

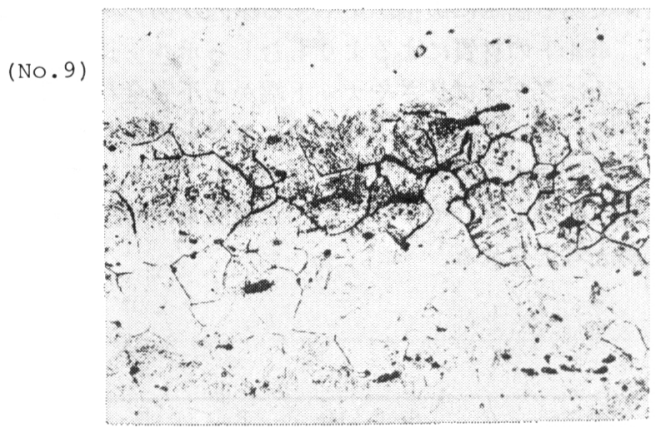

b) ミクロ偏析带内のみ現出

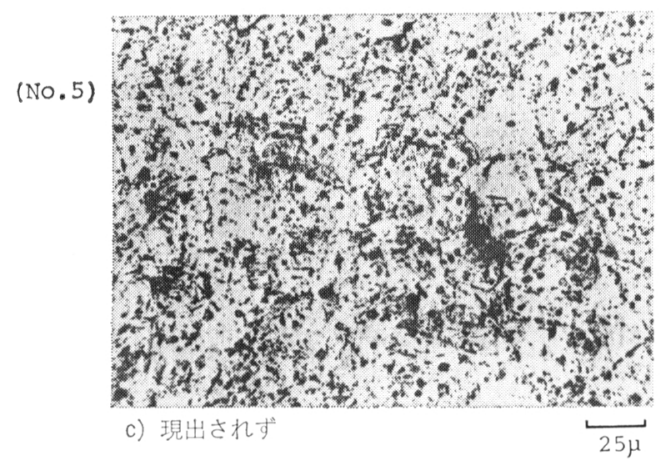

写真 1 旧オーステナイト粒界の現出度

は No. 1，4，ミク口偏析帯の中での久現出されたのは No. 2, 3, 7, 8, 9, 12，13，現出されにくからたのは No. 5，10，11 であつた。

\section{5. 破損の統計的特徴}

\section{$5 \cdot 1$ ボルト破損の確率分布}

No. 4 の F 13 T ボルトについてはボルト破損が継手 の強度を急速に低下させる程多くはないこと, 橋梁下が 河川で破損ボルトが落下しても危険がないなどの理由か ら，約 15 年間にわたり破損傾向を観察した。この結果 をワイブル確率紙にプロットしたのが図 3 である.

二母数ワイブル分布の確率密度関数は, 寿命を $t$ とす ると， 


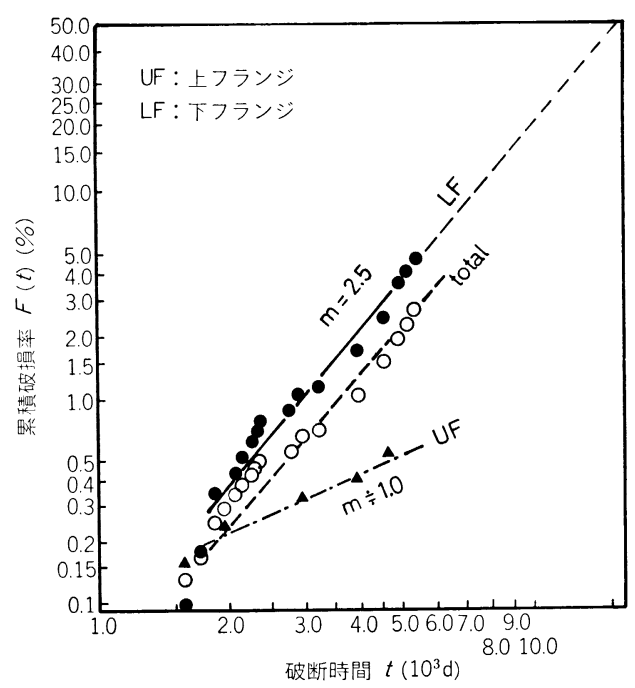

図 3 F 13Tボルトの破断寿命のワイブル・プロット

$$
f(t)=\frac{m}{\alpha} t^{\mathrm{m}-1} \exp \left(-\frac{t^{\mathrm{m}}}{\alpha}\right) .
$$

また故障率関数は

$$
\lambda(t)=\frac{m}{\alpha} t^{\mathrm{m}-1}
$$

と表される. ここで $m$ は形状母数, $\alpha$ は尺度母数であ る.

$m<1$ ならば故障率 $\lambda(t)$ は時間と共に低下する初期 故障形, $m=1$ ならば指数分布になり $\lambda(t)$ が時間によ らず一定な偶発故障形, $m>1$ ならば時間の 経過と共に $\lambda(t)$ が増大寸る摩耗故障形の破損分布になる.

図 3 にみられるよらに上フランジ継手 (UF) と下フラ ンジ継手 $(\mathrm{LF})$ を別々にプロットすると, 上フランジで は $m=1$, 下フランジでは $m \fallingdotseq 2.5$ となる. すなわち, 上フランジでは偶発形破損を示すから, 毎年ある一定数 のボルトを補充すればよいが，下フランジでは年々破損 率が増加するので保守上問題となる．橋梁全体では下フ ランジの破損率が高いので下フランジの破損傾向に従 万. 鉄道橋では継手のすべりに対する安全率を 1.8 と して設計するから，ボルトの $44 \%$ が破損すれば橋梁は 変状する.

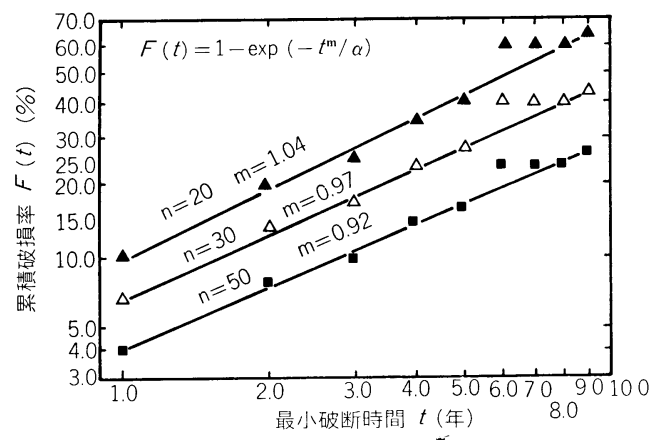

四 4 各橋梁における破損ボルトの最小破断時間の ワイブル・プロット（n:破損を生ずる可能性のあ る橋梁数)

上の結果から累積破損率が $44 \%$ に達する年数は約 40 年と推定される.

\section{$5 \cdot 2$ 最初のボルト破損を生ずるまでの寿命分布}

表 2 に示したボルトの破損が最初に発見されるまでの 時間をその橋梁での最小ボルト破損寿命として，1年ご との頻度を考える.この仮定は前述したように最初の破 損が発見された後に破損件数が集中する傾向があること から大きな䛊りではないと考えられる．各橋梁ごとのボ ルト破損確率分布は明らかではないが，最小寿命の分布 は遅れ破壊を生ずる可能性のある橋梁数を $n$ とすれば, 図 4 のように二母数ワイブル分布で表せる. 図から明ら かなように $m \leq 1$ であり， $n$ が大きくなる程初期故障形 になることがわかる.

現在 F 11 T の使用は中止されているから，これまで に F $11 \mathrm{~T}$ を用いて遅れ破壊を生じなかつた橋梁で今後 遅れ破壊を生ずる確率は時間と共に小さくなると考えら れる。

しかしながら, No. 7 のよらに 9 年後に破壊を生じは じめる例もあるから, 施工後 10 年末満の橋梁ではなお 監視が必要と考えられる.

\section{6. 高力ボルトの使用環境7)}

高力ボルトの腐食状況を調べるために, 高力ボルトを 使用しはじめた初期の橋梁ならびに表 2 に揭げた遅れ破 壊発生橋梁から 8 橋梁を選び主桁, 横桁, 鋼脚柱などか

\begin{tabular}{|c|c|c|c|c|c|c|c|c|c|c|}
\hline \multirow{2}{*}{ No } & \multirow{2}{*}{ 梁 楎 } & \multirow{2}{*}{ 造 } & \multirow{2}{*}{$\begin{array}{l}\text { 遅れ破賟 } \\
\text { の有 無 }\end{array}$} & \multirow{2}{*}{$\begin{array}{l}\text { 使用経過 } \\
\text { 年 数 }\end{array}$} & ボル & 卜 製 & \multicolumn{2}{|c|}{ 造 方 法 } & \multirow{2}{*}{$\begin{array}{l}\text { ボルト軸部 } \\
\text { 横断面最高硬さ } \\
\text { HRC }\end{array}$} & \multirow{2}{*}{$\begin{array}{c}\text { 硬さから推定した } \\
\text { 引張 强 } \\
\mathrm{kgf} / \mathrm{mm}^{2}\end{array}$} \\
\hline & & & & & 熱 処 & 理 & ねじ & 製 作 & & \\
\hline $\begin{array}{l}\mathrm{A} \\
\mathrm{B} \\
\mathrm{C} \\
1 \\
\mathrm{D} \\
3 \\
5 \\
8\end{array}$ & $\begin{array}{c}\text { I 型 リ } \\
\text { I 型 } \\
\text { 龬 } \\
\text { I 型 } \\
\text { 主 } \\
\text { 端横 } \\
\text { 箱 型 主 } \\
\text { 箱 型 主 } \\
\text { 型 }\end{array}$ & 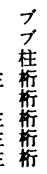 & $\begin{array}{l}\text { 無 } \\
\text { 無 } \\
\text { 無 } \\
\text { 有 } \\
\text { 無 } \\
\text { 有 } \\
\text { 有 } \\
\text { 有 }\end{array}$ & $\begin{array}{r}19 \\
19 \\
16 \\
14 \\
11 \\
8 \\
9 \\
4\end{array}$ & 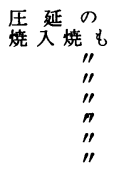 & ま ま & $\begin{array}{l}\text { 転 } \\
\text { 転 } \\
\text { 部 }\end{array}$ & $\begin{array}{l}\text { 造 } \\
\text { 削 } \\
\text { 造 } \\
\prime \prime \\
\prime \prime \\
\prime \prime \\
\prime \prime\end{array}$ & $\begin{array}{l}19.9 \\
26.5 \\
39.5 \\
38.7 \\
33.7 \\
38.8 \\
41.8 \\
39\end{array}$ & $\begin{array}{r}75 \\
85 \\
125 \\
122 \\
105 \\
120 \\
135 \\
120\end{array}$ \\
\hline
\end{tabular}

表 5 腐食調査のために採取したボルトの使用経歴および材質 
表 6 ボルト軸部から採取した腐食生成物の分析

\begin{tabular}{|c|c|c|c|}
\hline $\begin{array}{c}\text { 橋 梁 } \\
\text { No }\end{array}$ & $\alpha-\mathrm{FeOOH}$ & $\gamma-\mathrm{FeOOH}$ & $\mathrm{Fe}_{3} \mathrm{O}_{4}$ \\
\hline $\begin{array}{l}\text { A } \\
\text { B } \\
\text { C } \\
1 \\
\text { D } \\
3 \\
5 \\
8\end{array}$ & $\begin{array}{c}\mathrm{W} \\
\mathrm{M} \\
\mathrm{W} \\
\mathrm{M} \\
\mathrm{VW}\end{array}$ & $\begin{array}{c}\mathrm{W} \\
\mathrm{W} \\
\mathrm{VW} \\
\mathrm{VW}\end{array}$ & $\begin{array}{c}\text { VW } \\
\text { VS } \\
M \\
\text { S } \\
\text { VS } \\
\text { VS } \\
\text { VS } \\
\text { VS }\end{array}$ \\
\hline
\end{tabular}

らW7/8 のボルトを採取した。ボルトの使用されてい た桁構造, 顕微鏡組織から推定したボルト製造法, 硬さ の一覧を表 5 亿示す.

供試ボルトの軸部から鉄さびを採取しその組成を同定 するとともに軸部表面の凹凸を観察した。

鉄さびの分析結果を表 6 に示す. ボルト締結時に密閉 された状態で生じた不安定なさびは, 酸素の豊富な大気 に曝すと安定なさび系に変化するので，これらの結果は 使用中に生じたさび形態とは必ずしも一致はしないと考 えられる。

常温大気中で生成される鉄の 腐食生成物の主なもの は, オキシ水酸化鉄の Goethite $(\alpha-\mathrm{FeOOH})$ と Lepidocrocite $(\gamma-\mathrm{FeOOH})$ 及び Magnetite $\left(\mathrm{Fe}_{3} \mathrm{O}_{4}\right)$ など であるが，大気中の污染因子の影響によりこれらの相対 的割合は異なる。たとえば, 都市や工業地帯の上うに巠 硫酸ガスが含まれる環境では， $\alpha-\mathrm{FeOOH}$ が主成分とな る. この場合同時に検出されることの多い $\gamma-\mathrm{FeOOH}$ は不安定でしだいに $\alpha-\mathrm{FeOOH}$ に变化する. 他方, 海 岸など $\mathrm{Cl}^{-}$の濃度が高い環境では $\beta-\mathrm{FeOOH}$ が見出 されるのが特徴である ${ }^{8)}$. 表 6 の結果では $\mathrm{Fe}_{3} \mathrm{O}_{4}$ が主成 分であるが, No. 1， 3 では $\mathrm{SO}_{2}$ の影響がみられ $\alpha-$ $\mathrm{FeOOH}$ の生成が他よりる優勢であつた. No. A は建造 物内でありボルトも非調質で熱処理による酸化膜もなく 金属光沢を呈していた．遅れ破壊を生じた橋梁にのみ $\gamma-\mathrm{FeOOH}$ が検出されたが, さびの不安定さを考えると 破壊と直接的な関係を示すというょりはむしろ水の浸入
した形跡を示しているものと考えられる。な物 $\beta-\mathrm{FeO}$ $\mathrm{OH}$ はいずれの橋梁でも認められなかつた.

各ボルトの表面凹凸は熱処理肌の状態と同一であり， これらボルトの使用環境は著しい孔食や全面腐食を生ぜ しめるものではないと判断された。

表 5 に示した硬さからすれば No. C は遅れ破壊を十 分生じらる強度水準にあるが，このボルトは雨の直接か からない鋼脚柱に使用されて拈り腐食反応が生じなから たために破壊しなかつたものと考光らる.

\section{7. 破 壊 形 態}

\section{1 ボルトの破断部位}

ボルトの破断部位を首下，軸部，不完全ねじ，遊びね じ，ナットかかり端，ナット内枦し 6 箇所に分類して 示すと表 7 のようになる. 破損ボルトのらち一部は紛失 してこれらの詳細が不明のものがあるためこの表の破損 総数は表 2 のそれと必ずしも一致しない。

規格では首下に $10^{\circ}$ のくさびを入れて引張つたとき 首下で破断してはならないことが規定されているから， 一般には礼じ部が最弱点である，遅れ破壊の場合も不完 全対じ部の破断が多いが，No. 3，4，5 では首下破断が 多かつた.

この理由として第一に，これらがいずれも頭が下向き の場所で多発したことから水滴が首下にたまりやすかつ たこと，第二に首下 $\mathrm{r}$ の大きいボルトが座金の打ち抜き 出口側の $\mathrm{r}$ の小さい部分之組及合わさって首下にあたり を生じ，荷重が集中したことが考兄られる。

No. 7,9 飞みられた軸部の破断は首下に近い部分で あつたが，応力集中部である首下丸及部分より 5〜10 $\mathrm{mm}$ 離れた位置であり，孔食がき裂発生点になつたもの と考觉られる.これらの橋梁ではボルトの腐食程度は他 の橋梁より著しかつた。

\section{2 破 面}

破面は破損が発見された時点ではさびていることが多 く, とくに起点付近の詳細な観察が困難な場合が多い.

写真 2 亿破面外観の例を示与. 破壊起点は（a)のよ5

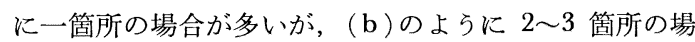

表 7 ボルト破断部位の分布

\begin{tabular}{|c|c|c|c|c|c|c|c|}
\hline \multirow{2}{*}{$\begin{array}{l}\text { 橋梁 } \\
\text { No }\end{array}$} & \multicolumn{3}{|c|}{ 破 } & \multirow{2}{*}{$\frac{\text { 断 }}{c}$} & \multirow{2}{*}{$\frac{\text { 部 }}{\mathrm{d}}$} & \multicolumn{2}{|l|}{ 位 } \\
\hline & a & b & & & & e & $\mathrm{f}$ \\
\hline 1 & 1 & 0 & & 0 & 0 & 0 & 0 \\
\hline 2 & 1 & 0 & & 2 & 0 & 0 & 0 \\
\hline 3 & 7 & 0 & & 0 & 2 & 0 & 0 \\
\hline 4 & 26 & 0 & ( & & 14 & ) & 0 \\
\hline 5 & 4 & 0 & & 0 & 0 & 0 & 0 \\
\hline 6 & 0 & 0 & & 7 & 4 & 2 & 0 \\
\hline 7 & 2 & 2 & & 5 & 3 & 1 & 0 \\
\hline 8 & 0 & 0 & & 9 & 5 & 2 & 0 \\
\hline 9 & 0 & 4 & & 5 & 10 & 1 & 1 \\
\hline 10 & 0 & 0 & & 2 & 0 & 1 & 0 \\
\hline 11 & 0 & 0 & & 1 & 1 & 2 & 0 \\
\hline 12 & 0 & 0 & & 1 & 1 & 1 & 0 \\
\hline 13 & 0 & 0 & & 1 & 0 & 0 & 0 \\
\hline
\end{tabular}

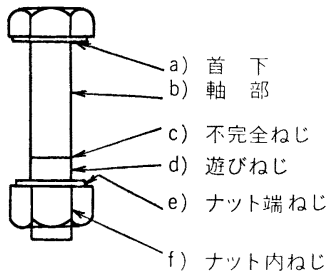




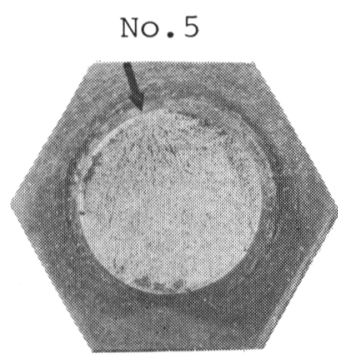

(a)

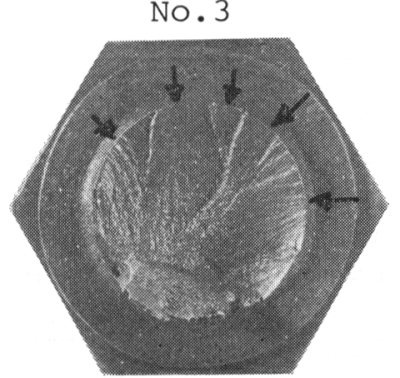

(b)
No. 3

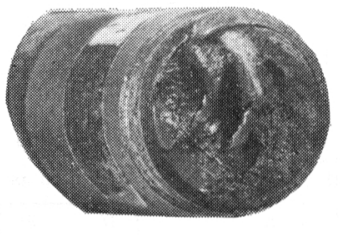

(c)

写真 2 破面外観の代表例

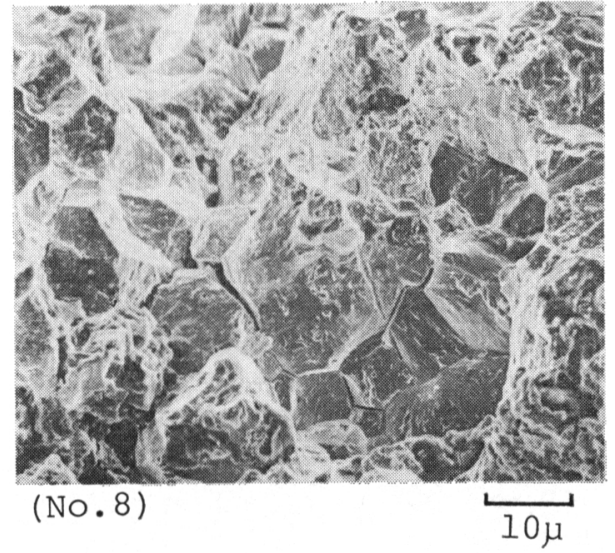

军真 3 破面起点部にみられる粒界割れ
合もある.とくに表面下に硬化層の存在していた No. 3 では円周状に多数の起点が認められた.

写真 3 は起点部を走查型電子顕微鏡で抎大観察した例 で，一般に旧オーステナイト粒界割れがタられた。

写真 2 の ( c) はボルト軸方向に沿つた縦割れがみられ た例で, 前述の腐食液を用いるとき裂はミク口偏析帯に 沿つた粒界割れであることが示された。

\section{8. 遅れ破壊感受性と材質的問題点}

一部の橋梁については, ボルト破損を生じた継手から 破損していないボルトを数本採取し，これから試験片を 削出して JIS 原案による遅れ破壊試験†を行つた。この 結果得られた遅れ破壞曲線を図 5 に示す。これより求め た 100 時間強度を遅れ破壊限度 $\sigma_{\mathrm{d}}$ とし, 大気中での 切り欠き曲げ強さ $\sigma_{0}$ に対する比を遅れ破壊限度比とす る.これらの結果を硬さの順に並べて比較すると表 8 の

$\dagger$ 先端半径 $0.1 \mathrm{~mm}$, 深さ $2 \mathrm{~mm}$, 開き角 $45^{\circ}$ のV切り欠きを片側に 有する $10 \times 10 \mathrm{~mm}$ 断面の角棒切り欠き曲げ試験片を $\mathrm{pH}=2.0$ の 緩衙溶液（酢酸ナトリウム十塩酸）中で定荷重片持曲げ負荷を与え

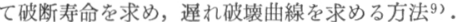

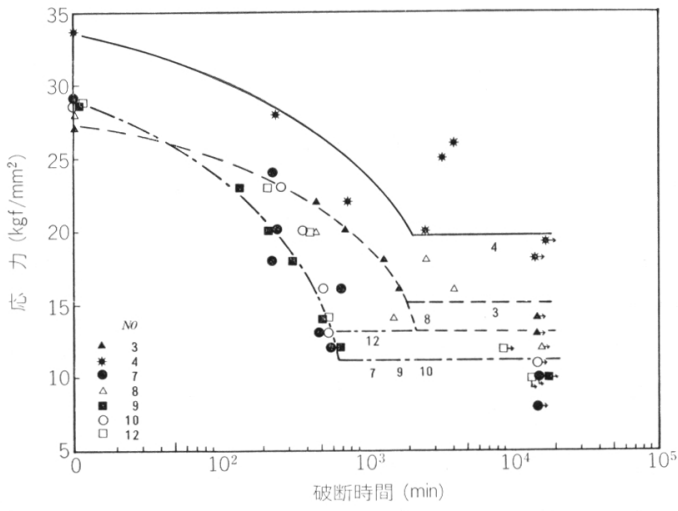

図 5 破損ボルト鋼の遅れ破壊試験結果 (JIS 原案法)

ようになる。

ここにみられる特街は, 第一に遅れ破壊感受性は必ず しも硬さの順とは一致しないこと, 第二は破壊感受性を 大きい順に大別すると $\sigma_{\mathrm{d}} / \sigma_{\mathbf{0}}=0.42 \sim 0.45$ (No. 7, 9, $10,12), \sigma_{\mathrm{d}} / \sigma_{0}=0.50 \quad$ (No. 8), $\sigma_{\mathrm{d}} / \sigma_{0}=0.58 \sim 0.60$ (No. 3，4) の三つに分けられること，第三は F 13 T (No.4) は高強度であるにもかかわらず破壊感受性は $\sigma_{\mathrm{d}} / \sigma_{0}=0.60$ と最小であつたことである。

試験片は切り欠きがボルト表面直下になるよう採取し たが，切り欠き底部は前述のよらに硬化層や軟化層のあ るボルト表面とは破壊感受性が異なることの活か，使用 条件などの諸条件が異なるために実橋での結果と促進試 験結果にある程度差異を生ずるのは避けられない。

表 8 には参考のために, 梁構造, B 执よび $\mathrm{P}$ 含有率, 粒界の腐食による現出度を分類して示した. 破損本数は 前述のように観察期間の長さや使用条件に依存するから 材料の破壊感受性を必ずしも反映しないためここでは考 察の対象とはしなかつた。

遅れ破壞を生じたボルトの最小硬さは HRC 37.5 で あつた。これは従来の実験結果10)で認められている最小 
表 8 破損ボルト鋼の遅秃破壊感受性と材質

\begin{tabular}{|c|c|c|c|c|c|c|c|c|c|c|c|c|c|}
\hline 橋 $\quad$ 梁 $\mathrm{Na}$ & 8 & 12 & 3 & 5 & 1 & 7 & 9 & 6 & 11 & 10 & 13 & 4 & 2 \\
\hline 梁 構 造 ${ }^{1)}$ & B & B & B & B & I & B & B & I & B & I & I & I & B \\
\hline さ $\mathrm{HRC}$ & 37.5 & 38 & 38 & 39 & 40 & 40 & 40.5 & 41 & 42 & 42 & 44 & 45 & 46 \\
\hline 遅れ破壊限度 $\sigma_{\mathrm{d}}\left(\mathrm{kgf} / \mathrm{mm}^{2}\right)$ & 121 & 113 & 138 & - & - & 105 & 105 & - & - & 113 & - & 175 & - \\
\hline 切久曲げ強さ $\sigma_{\circ}\left(\mathrm{kgf} / \mathrm{mm}^{2}\right)$ & 244 & 250 & 236 & - & - & 253 & 249 & - & - & 249 & - & 290 & - \\
\hline 遅九破壊限度比 $\sigma_{\mathrm{d}} / \sigma_{\circ}$ & 0.50 & 0.48 & 0.58 & - & - & 0.42 & 0.42 & - & - & 0.45 & - & 0.60 & - \\
\hline $\mathrm{B}$ 含有率 ppm & 37 & 40 & - & 23 & 8 & 47 & 20 & - & 20 & 4 & - & - & - \\
\hline $\mathrm{P}$ 含 有率 $\mathrm{ppm}$ & 170 & 100 & 200 & 90 & - & 100 & 180 & 150 & 100 & 70 & - & 170 & 130 \\
\hline 粒 界 現 出 度 ${ }^{2}$ & $\mathrm{~b}$ & $\mathrm{~b}$ & b & c & \begin{tabular}{|l|}
$a$ \\
\end{tabular} & b & $\mathrm{b}$ & - & $\mathrm{c}$ & $\mathrm{c}$ & $\mathrm{b}$ & $\mathrm{a}$ & $\mathrm{a}$ \\
\hline
\end{tabular}

注) ${ }^{12} \mathrm{~B}$ : 箱析, I : I 形妳. ${ }^{22} \mathrm{a}$ : 全面, b : 偏析帯内のみ, c : 現出されず.

$\square$ は, $\mathrm{HRC} \sum 41, \mathrm{~B} \geqq 25, \mathrm{P}>150$, 粒界現出度 $\mathrm{a}$ の範围を示す。

強度, $\sigma_{\mathrm{B}}=130 \mathrm{kgf} / \mathrm{mm}^{2}$, 硬さ $\mathrm{HRC}=41$ に比べると低 い值である。乙たがつて $\mathrm{HRC}<41$ で破壊を生じ淰ボ ルトの場合，何らかの材質的鋭敏化原因があつたと推定 される。

气の第一は浸炭である。表面下の硬さ分布から浸炭傾 向が明膫なのは No. 3 のみであつた.No. 3 は破損し ていないボルトにも首下や称じ谷に粒界き裂を生じてい るものが多数岕つた。この残存き裂は図 2 に示す $\mathrm{HV} \geq$ 400 の硬化域に生じ平均長さは $0.2 \mathrm{~mm}$ であつた。同一 の継手に使用されたボルトのらちに硬さが HRC 41 を越光るものもあつたが，表面硬化層がない場合には残 存き裂は名られなかつた。

機械ボルトのよらに疲労強度が問題になる場合には, 熱処理時の脱炭は避けなければならないが，遅机破壇が 対象になる場合には主し万脱炭傾向が望ましい。

材質的鋭敏化原因の第二は粒界不純物偏析による粒界 脆化である．市肘の低合金鋼で粒界脆化を生ぜしめる主 なものはPであるＰの粒界偏析は前述のピクリン酸系 腐食液で検出されるが，一般に焼もどし温度が高くなる と検出が因難になる。表 2 亿示すように低強度側で粒界 現出度が低下するのはこのためである。この現象は焼も ぞし温度の上昇と共に $\mathrm{P}$ の偏析量が減少するためではな く, 炭化物の粒界析出形態と関連した粒界腐食度の変化 によるものと考兄られる ${ }^{11)}$ 。粒界割れは粒界が現出され る場合に生じやすいから，この場合にもPの偏析だけで なく炭化物の析出形態が重要な寄与をしていると考光ら れる12)、すなわち焼もどし温度が上昇吉れば粒界炭化物 が凝集 し，転位障害効果が減少寸るため粒界割れ感受性 は低下寸る。市販鋼の場合，低燐化には限度があるか ら，炭化物形態制御すなわち焼もどし温度管理が重要で ある。

な特 $\mathrm{S}$ も粒界に偏析するが， $1050^{\circ} \mathrm{C}$ 以下でオーステ ナイト化した場合には，Sが単独で存在するよりも硫化 物として析出する垃粒界凝集力低下に奇与しないとい ら結果 ${ }^{13)}$ がある。

第三は破壊感受性の大きいボルト材に含有されている

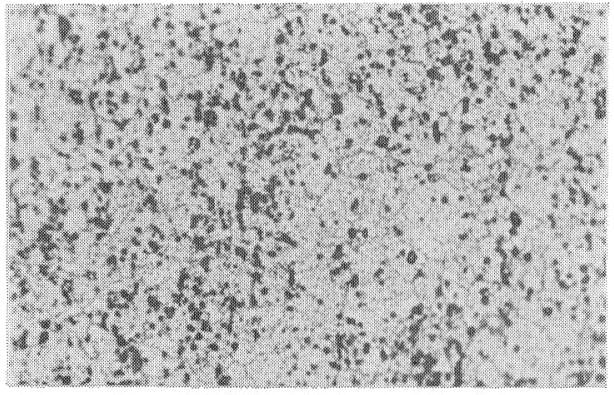

No. 8

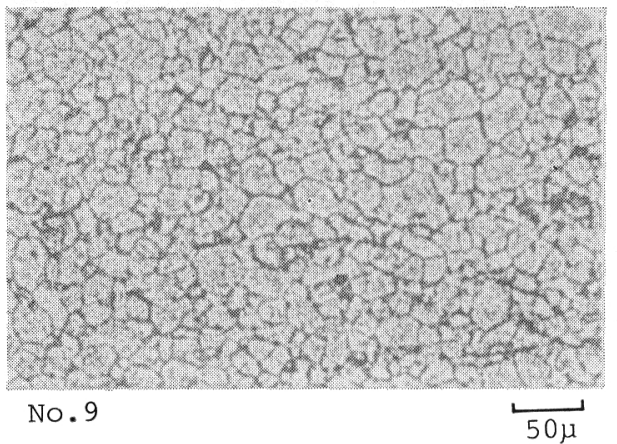

写真 $4 \quad \alpha$ トラックェッチング法による $\mathrm{B}$ の分布状態

Bである。一般に焼入性向上に必要な B の最適添加量は 3〜25 ppm といわ机ている14)15). これに対し No. 7, 8，12 では明らかにこの範团を越克ている。過剩にBが 含ま礼ると粒界に硼炭化物 $\mathrm{Fe}_{23}(\mathrm{~B}, \mathrm{G})_{6}$ が析出与る 15). 写真 4 は No. 8,9 の軸部表面下に拈けるBの分布 状態を $\alpha$ トラック・エッチング法16)で観察したもので ある。この結果では，No. 9 は粒界にBが存在している が，No. 8 ではその傾向が久られない。しかし両者共に 粒界割れを生じているからBが粒界割れの原因であると は必ずしも結論できないが，嗍炭化物が粒界炭化物と同 様の機能を果たすことによつて粒界割れ感受性を高める ことはあるか子知机ない。 


\section{9. ま と め}

実橋に拈ける高力ボルトの遅れ破壊に関する事例解析 結果をまとめると次のようになる.

1) 橋梁の桁構造別にみると箱桁に括ける損傷例が多 かつた。これは桁内部に水が溜まるために日照時には高 温高湿条件となり腐食反応が生じやすいためである。し たがつて, 箱桁には水抜き孔を設けて桁内部が乾燥状態 を保つようにすることが破損防止上必要である.

2) 橋梁によつて破損が上フランジ，ウェブ，下フラ ンジなどのある箇所に集中する傾向が認められた.この 原因は明らかではないが, ボルトの遊びねじ長さ, 水滴 の溜まりやすさ, 温度上昇度など, ボルトの製造ロット 別に生ずる材質的差異以外の要因が考光られる.

3) ボルトの破断部位は不完全ねじ部が一般的には多 いが，橋梁によつては首下破断が多発する場合もあつ た．規格上は首下はねじ部より強い筈であるから，首下 破断を生ずる理由には, 第一に頭が下向きの場合首下に 水滴が溜まりやすいこと, 第二に首下の丸み部に座金の 角があたり荷重が集中したことが考えられる.とくに後 者の場合には座金が遅れ破壊してボルト孔内部への水の 浸入を容易にすることもある10)ので, 座金の内側隅は十 分面とりする必要がある.

4) F $13 \mathrm{~T}$ (No. 4) を適用した唯一の橋梁で約 15 年間にわたりボルトの破損傾向を追跡調査した. その結 果ボルト破損の確率分布は二母数ワイブル分布に従うこ とが認められた．継手のすべりに対する安全率を考える と, 破損の補修をしなかつた場合にはこの橋梁は約 40 年で変状を生ずると推定された。

5） F $11 \mathrm{~T}$ を使用した橋梁で最初の破損を生ずるま での寿命分布も二母数ワイブル分布で表され, 故障率が 時間と共に低下する傾向を示した. 現在 F $11 \mathrm{~T}$ の使用 は中止されているから, すでに F $11 \mathrm{~T}$ を使用している 既設の橋梁での遅れ破壊事例は今後減少傾向にあると推 定される.

6) 高力ボルトを適用した初期の橋梁や遅れ破壊を発 生した橋梁についてボルトを採取して軸部の鉄さびの分 析を行つた，直接雨に曝された箇所や箱桁ではボルトが 湿つた状態にあるものが多かつたが，鉄さびの組成から も水の存在が認められた，遅れ破壊は水の存在下で腐食 反応の結果生ずる水素により誘起されるもので, 乾燥状 態で使用されていれば遅れ破壊は生じない。

7) 破面の破壊起点部には旧オーステナイト粒界割れ がみられた．材料によつては破壊途中で王延方向にミク 口偏析帯に沿つて 粒界割れを生ずる縦割れが認められ た。

8) 遅れ破壊を生じたボルトの最小硬さは HRC 37.5 であつた，従来の実験から得られた遅れ破壊を生ずる限 界硬さは HRG 41 であるから，HRC<41 で破損した
ボルトは材質的鋭敏化原因があつたと考えられる，その 原因として，浸炭による表面硬化，Pの粒界偏析， B の 粒界に拈ける存在などが考兄られた。これらの原因の検 討から，熱処理炉の雾囲気は脱炭傾向にすること，可能 な限り低燐の高純度鋼を用いること，B添加は必要最少 量にすることなどが高力ボルトの信頼度を高めるために 必要であると結論される，しかし市販鋼では高純化には 限度があるから粒界炭化物が十分凝集するまで焼もどし 温度を高めることが必要である.

9）一般に炭素量が多いと焼もどし軟化曲線の勾配が 急になり，焼もどし温度変化の硬さへの影響が大きくな るから，炭素量の多い鋼種で高強度化するのは望ましい ことではない．またバッチ型焼もどし炉のように装入力 法によつては温度むらを生ずる場合には，一部に焼もど しが不十分で硬さの高い製品が混入する可能性があるの で注意が必要である.

\section{0. あとがき}

実用上の遅れ破壊は 1950 年代に米国で航空機用高力 ボルトのめつき脆性として問題化したが, 我が国で最初 に問題になつたのはここに紹介した橋梁用高力ボルトの 破損である.

その発端になつたのは F 13 T ボルトの実用化であつ たが，その経験が我が国の水素脆性研究の発展に対する 大きな衝撃となつた. その後この分野での研究は精力的 に進められ，実用的な問題点は周知のものとなつている 筈であるが, とくに JIS B 1186 以外の各種高力ボルト にはな颃破損事例が跡を絶えない．これが破損事例の単 なる歴史的総括以外に本稿ををとめたもら一つの動機で もある.

本調査に当たつては，埼玉大学，田島二郎教授の有益 な御教示，国鉄構造物設計事務所，佐々木秀弥氏，鉄道 技術研究所, 青木純久, 末木清高, 石井羊子諸氏及び高 カボルトメーカーの御協力を賜つた。 また $\alpha$ トラック・ エッチングは新日鉄，基礎研究所に御協力をいただい た.ここに記して謝意を表します。

\section{文献}

1）田島二郎：高力ボルト摩擦接合概説（1966）［技 報堂]

2 ) 伊藤 篤, 松山晋作：鉄道技術研究資料, 26 (1969)，p. 93

3 ) 松山晋作：鉄道技術研究資料，28 (1971)， p. 32

4) 青木純久, 松山晋作：鉄道技術研究資料, 36 (1979)， p. 245

5 ）鈴木信一：水素による遅れ破壊の機構（鉄鋼基礎 共同研究会, 遅れ破壊部会報告書) (1975) p. 179 [日本鉄鋼協会]

6 ）松山晋作：鉄と鋼，69 (1983), p. 136

7 ) 松山晋作, 末木清高, 石井羊子, 滝永 進, 佐々 木秀弥：鉄道技術研究資料, 38 (1981)， p. 373

8 ) 青山芳夫: 色材， 39 (1976)，p. 305

9 ) 建材試験センター：構造材料の安全性に関する標 
準化のための調査研究・報告書 $(1981,3)$, p. 72

10) ボルト強度班: JSSC, 15 (1979) 158, p. 21

11）山中和夫, 大森靖也：鉄と鋼, 64 (1978), p. 1162

12) $C . L$. Briant and $S . K$. Banerji: Metall. Trans., $10 \mathrm{~A}$ (1979), p. 1151

13) $C . L$. Briant and $S . K$. Banerji: Metall.
Trans., 12 A (1981), p. 309

14）渡辺征一，大谷泰夫，邦武立郎：鉄と鋼，64 (1978), p. 113

15) G.F. Melloy, $P . R$. Slimmon, and $P . P$. Podgursky: Metall. Trans., 4 (1973), p. 2279

16) J.D. Hughes and $G . T$. Rogers: J. Inst. Metals, 95 (1967), p. 299

\begin{tabular}{|c|c|c|c|c|}
\hline \multirow{2}{*}{$\begin{array}{c}\text { 世界同時不況を背景とした } 1982 \text { 年の内外鉄鋼業は, } \\
\text { 西側先進諸国ではわが国の粗鋼生産 } 10 \text { 年ぶりの } 1 \text { 億 } \\
\mathrm{t} \text { 割れ, アメリカの } 40 \% \text { を切る低操業, EC の強制 } \\
\text { 減産措置の延長など, いずれも極度の需要不振と大幅 } \\
\text { 減産に見舞われ, の苦境克服が共通の課題であつた. } \\
\text { また, 共産圏諸国では, ソ連は } 1982 \text { 年も計画を下 } \\
\text { 回る生産となり, 粗鋼 } 1.5 \text { 億 } \mathrm{t} \text { へ回復はできなか } \\
\text { つた. ポーランドの生産も引き続き後退した. ただ, } \\
\text { 中国の生産が順調に回復し, 粗鋼生産高で大幅減とな } \\
\text { つた西ドィッを上回つた. } \\
\text { 中進製鉄国でも総じて不振は避けられなかつたが, } \\
\text { 主要国の粗鋼生産推移 }\end{array}$} & \multicolumn{4}{|c|}{$\begin{array}{l}\text { 韓国, 台湾の生産は増大した. } \\
\text { この結果, } 1982 \text { 年の世界粗鋼生産高は } 6 \text { 億 } 4500 \\
\text { 万 } \mathrm{t} \text { と前年実績を } 9.1 \% \text { 下回つて } 7 \text { 億 } \mathrm{t} \text { の大台を } 5 \\
\text { 年ぶりに割つた. } \\
\text { わが国鉄鋼業は, 内外需要の不振と在庫調整の遅れ } \\
\text { によつて年央以降, 大幅減産を余儀なくされ, 高炉の } \\
\text { 相次ぐ休止や雇用調整などが進められた. こうした中 } \\
\text { で輸入鋼材は增勢をたどり, 安值輸入品の市況への影 } \\
\text { 響が問題となつた. } \\
\quad \text { 世界の粗鋼生産高（単位 }: 100 \text { 万 } \mathrm{t} \%)\end{array}$} \\
\hline & \multicolumn{4}{|c|}{\begin{tabular}{l|l|l|l|l|} 
順位 & 国 & 名 & 1982 & 堌 減 率 \\
\end{tabular}} \\
\hline 主要国の粗鋼生産推移 & $\begin{array}{c}1 \\
2 \\
3 \\
\\
\\
4 \\
5 \\
6 \\
7 \\
8 \\
9 \\
10 \\
11 \\
12 \\
13 \\
14 \\
15 \\
16 \\
17 \\
18 \\
19 \\
20\end{array}$ & 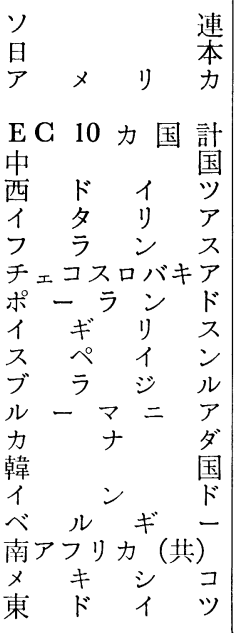 & $\begin{array}{r}147.5 \\
99.5 \\
65.7 \\
(67.2) \\
111.1 \\
37.0 \\
35.9 \\
24.0 \\
18.4 \\
15.0 \\
15.0 \\
13.8 \\
13.1 \\
13.0 \\
13.0 \\
12.1 \\
11.8 \\
11.1 \\
9.7 \\
8.6 \\
7.1 \\
7.1\end{array}$ & $\begin{array}{r}\triangle 0.7 \\
\triangle 2.1 \\
\triangle 40.1 \\
(\triangle 40.1) \\
\triangle 11.9 \\
3.9 \\
\triangle 13.7 \\
\triangle 3.2 \\
\triangle 13.2 \\
\triangle 2.0 \\
\triangle 4.5 \\
\triangle 9.8 \\
\triangle 1.6 \\
\triangle 1.5 \\
0.0 \\
\triangle 18.2 \\
9.3 \\
2.8 \\
\triangle 21.1 \\
\triangle 4.4 \\
\triangle 6.6 \\
\triangle 5.3\end{array}$ \\
\hline & & 世 界 合 計 & 645.0 & $\triangle 9.1$ \\
\hline \begin{tabular}{c|c}
$\frac{1}{1}$ & 1 \\
78 & 80
\end{tabular} & \multicolumn{4}{|c|}{ 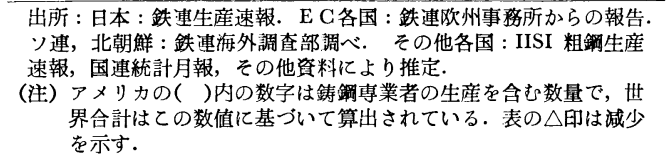 } \\
\hline
\end{tabular}

